\section{Injuries in epilepsy: a review of its prevalence, risk factors, type of injuries and prevention}

\author{
Rita Nguyen, ${ }^{1}$ José F. Téllez Zenteno \\ 'Division of Neurology, Department of \\ Medicine, University of Saskatchewan, \\ Saskatoon, SK, Canada
}

\section{Abstract}

Currently, there is intense clinical research into various aspects of the medical risks relating to epilepsy, including total and cause-specific mortality, accidents and injuries in patients with epilepsy and mortality related with seizures. Seizures occurring in precarious situations and resulting in injuries are still an important concern for patients with epilepsy, their employers and their caregivers. Submersion injuries, motor vehicle accidents, burns, and head injuries are among the most feared epilepsy-related injuries. These concerns seem valid because the hallmark of epilepsy, episodic impairment of consciousness and motor control, may occur during interictal EEG epileptiform discharges, even in the absence of a clinical seizure. In addition, psychomotor comorbidity and side effects of antiepileptic drugs may contribute to the risk of injuries in patients with epilepsy. Published risk factors for injuries include the number of antiepileptic drugs, history of generalized seizures, and seizure frequency. In general, epidemiological information about incidence of injuries has been conflicting and sparse. In general, studies focusing on populations with more severe forms of epilepsy tend to report substantially higher risks of injuries than those involving less selected populations. On the other hand, studies based on non-selected populations of people with epilepsy have not shown an increased frequency of injuries in people with epilepsy compared with the general population. Some studies have shown that patients with epilepsy are more frequently admitted to the hospital following an injury. Possible explanations include: more cautious attitude of clinicians toward injuries occurring in the setting of seizures; hospitalization required because of seizures and not to the injuries themselves; and hospitalization driven by other issues, such as comorbidities, which are highly prevalent in patients with epilepsy. Potentially the high rate of hospitalizations could be related with the severity of the injury. This article reviews the best available epidemiological information about injuries, including incidence and risk factors. Also this article reviews information about specific types of injuries such as fractures, burns, concussions, dislocations, etc. Information about accidents in people with epilepsy is also discussed.

\section{Introduction}

Epilepsy is a clinical phenomenon diagnosed by the occurrence of two or more unprovoked seizures. It is estimated that approximately 0.5$2 \%$ of the population suffers from a seizure disorder. ${ }^{1}$ People with epilepsy (PWE) are at increased risk for seizure-related injury, and it is reported that PWE also have higher incidences of home, street, and work accidents, even without a seizure. ${ }^{1}$ These may be due to interictal EEG epileptiform discharges occurring in the absence of obvious clinical seizure activity. ${ }^{2,3}$ PWE are more likely to die as a result of an accident than non-epileptic patients, and a person with epilepsy has a $5 \%$ chance per year of visiting an emergency department due to a seizure-related injury. ${ }^{4,5}$

Fortunately, the majority of seizure-related injuries are non-fatal, with the most common injuries being burns, fractures, soft-tissue injuries, and submersion accidents. Risk factors for injuries associated with epilepsy include seizure frequency, type of seizure, and associated use of anti-epileptic drugs. PWE also suffer from other comorbid conditions such as a learning disability, somatic and psychiatric comorbidity that puts them at an increased risk for accidental injury. Because of the increased risk of injury, PWE are subject to employment, recreational, and driving restrictions. These limitations have personal and social consequences, leading to inactivity, isolation, and dependency.

Although it is widely known that PWE are at increased risk for accidental injury as compared to the general population, there are conflicting reports in the literature and some of them have shown a similar risk of injuries. The contradictory results are due to a number of factors, including the population type in the study, the definition of epilepsy used in the study, accuracy of injury reporting, study design, and length of observation period.

This article reviews the best available epidemiological information about injuries, including epidemiological information such as incidence and risk factors, along with information about specific types of injuries such as fractures, burns, concussions, and dislocations.

\section{Epidemiology of seizure-related injuries}

The literature provides conflicting data
Correspondence: José Francisco Téllez-Zenteno, Division of Neurology, Department of Medicine, Royal University Hospital 103 Hospital Drive, Box 26, Room 1622, Saskatoon, SK S7N OW8 Canada. E-mail: jft084@mail.usask.ca

Key words: injuries, epilepsy.

Conflict of interests: the authors report no conflicts of interest.

Contributions: RN and JT contributed to the literature search, the drafting and the writing of the manuscript. All authors read and approved the final manuscript.

Received for publication: 4 September 2009. Revision received: 13 November 2009.

Accepted for publication: 13 November 2009.

This work is licensed under a Creative Commons Attribution 3.0 License (by-nc 3.0).

(C) Copyright R. Nguyen, J.F. Téllez Zenteno, 2009 Licensee PAGEPress, Italy

Neurology International 2009; 1:e20

doi:10.4081/ni.2009.e20

regarding the risk of accidental injury in PWE, with most studies overestimating the risk of injuries. The variation in data results from differences in the study population, with population-based samples providing a more accurate picture than referral patients, who often suffer from more severe disease. Conflicting results can also be due in part to differences in defining the disease (idiopathic, cryptogenic, or symptomatic), the accuracy of injury reporting (types of injury, circumstances, severity), the study design (retrospective versus prospective) and the length of the observation period. Selection bias is the most important explanation for inconsistent results, as patients with symptomatic epilepsy and frequent seizures have a higher prevalence of accidents and injuries than those with milder symptoms. ${ }^{6}$

The largest study assessing the risk of accidents in PWE was performed by Beghi et al. ${ }^{7}$ The study involved 951 referral patients with idiopathic, cryptogenic, or remote symptomatic epilepsy, followed for 17,484 person-months along with matched controls (relatives or friends). The majority of patients (55\%) suffered from partial epilepsy, and 37\% suffered from generalized epilepsy. Eighty-three percent of subjects experienced a seizure within the last two years and in the majority of cases, seizure frequency was less than one per month. Two hundred and seventy accidents were reported by 199 epileptic patients, and 149 accidents by controls. The most common injuries both in subjects with epilepsy and control subjects were contusions and wounds, followed by abrasions and fractures. PWE experi- 
enced a higher percentage of wounds, abrasions, and head concussions than controls, and this difference was statistically significant Twenty-four percent of the accidents were seizure-related. Among PWE, the relative risk of experiencing one accident was $1.2\left(\mathrm{CI}_{95}: 1.0\right.$ 1.3), and the RR of experiencing two accidents was $1.4\left(\mathrm{CI}_{95}\right.$ : 1.2-1.6). The cumulative probability of accidents in cases with epilepsy was $17 \%$ and $27 \%$ by 12 and 24 months, compared to $12 \%$ and $17 \%$ in controls $(\mathrm{P}<0.0001)$. The cumulative risk of accidents decreases significantly (14\% and 22\%) when seizure-related events are excluded. However, PWE were still found to have a higher rate of accidents than controls. The authors concluded that most epileptic patients suffer from trivial injuries, and although they do experience a higher incidence of injuries, the increased risk is modest, and is decreased significantly when seizurerelated incidences are controlled for. Patients with epilepsy who are appropriately managed are not at any significantly higher risk of accidents than the general population.

In a recently published, retrospective, population-based study of 247 persons with epilepsy, conducted by Lawn et al. ${ }^{8}$ patients were followed for 2,714 person-years. The majority of patients suffered from partial seizures, followed by generalized seizures. In the follow-up period, $16 \%$ of patients experienced at least one seizure-related injury. The majority of injuries were mild head injuries. Sixty-six percent of the injuries were single injuries, and $34 \%$ were multiple injuries (limb contusions with mild head injury). Eight percent of injuries required hospital admission. The cumulative risk of injury was $5.4 \%$ at one year $\left(\mathrm{CI}_{95}: 2.5-8.2\right), 12.7 \%$ at five years $\left(\mathrm{CI}_{95}: 8.0\right.$ $17.0), 14.6 \%$ at ten years $\left(\mathrm{CI}_{95}: 9.5-19.3\right)$ and $26.1 \%$ at 20 years $\left(\mathrm{CI}_{95}: 15.6-35.3\right)$. The authors of this study also concluded that the risk of seizure-related injury in PWE is small, and most injuries are minor and do not carry any adverse social or occupational consequences. The most important consideration in this study is the lack of a control group; this bias could overestimate the cumulative risk of injuries.

The most recent population-based study on the prevalence of injuries in PWE is a Canadian study presented by Tellez-Zenteno et $a l .{ }^{3}$ The study analyzes the prevalence of injuries among people with self-reported epilepsy, with the data obtained by the Canadian Community Health Survey, a door-todoor, cross-sectional survey that collects data pertaining to health status, use of health resources, and determinants of health of the Canadian population. The weighted prevalence of epilepsy was determined to be 5.6 per 1,000 $\left(\mathrm{CI}_{95}\right.$ : 5-7). The relative risk of injuries causing limitation of normal activities was higher in persons with epilepsy; however, the overall difference from the general population was not significant. The most common injuries in both the general population and persons with epilepsy were orthopedic injuries (broken/fractured bones, dislocations, sprain/strain), followed by superficial injuries (cuts, scrapes, burns), and lastly concussions/internal injury.

PWE experienced a higher frequency of burns, scaldings, or poisonings than the general population; however, the sample sizes were too small to make any accurate analysis. There was no difference in rates of orthopedic injuries and superficial injuries between PWE and the general population. PWE have a higher frequency of falls than the general population; however, this difference was not statistically significant. PWE were also found to be admitted to hospital three times more frequently than the general population following an injury. From the results of this populationbased survey, the authors concluded that the prevalence of injuries overall and of most specific injuries did not differ between persons with epilepsy and the general population. The most significant difference between PWE and the general population was the higher rate of hospital admission following an injury in PWE.

Thus, from the data found in the largest study on epilepsy and injuries, ${ }^{1,7}$ and the two most recent population-based reports, ${ }^{3,8}$ it can be concluded that although the risk of injuries in epileptic patients is higher than that of the general population, the difference is not extraordinary, and the majority of injuries are minor and do not cause significant disability or limitation of normal activities (Table 1).

\section{Fractures}

One of the most common injuries PWE suffer from is fractures. This may be due to the inability to activate protective reflexes during a seizure, resulting in falls and subsequent fracture. Seizures also cause an increased load on the skeleton due to muscle contractions during convulsions, leading to crush fractures of the spine or fractures of the humerus. ${ }^{16,17}$ Some anti-epileptic drugs are also known to decrease bone mass density, which plays a role in increasing the fracture risk among epileptics. PWE are most likely to sustain a fracture within the first one to two years after diagnosis. ${ }^{18}$

In a recent meta-analysis of the literature on fracture risk in epilepsy, it was found that PWE are approximately twice more likely to sustain a fracture than normal controls. ${ }^{19}$ Increase in hip fracture ranged from 2.3-12.1, with a pooled estimate relative risk of 5.25 $(\mathrm{P}<0.01)$. The risk of forearm fractures ranged from 1.6-3.2, with a pooled estimate RR of 2.53 $(\mathrm{P}<0.02)$. PWE were also at increased risk for spine fractures, with the relative risk ranging from 2.36-6.2, and a pooled estimate RR of 6.16
$(\mathrm{P}<0.49)$. These results agree with the population-based retrospective study of Souverein $e t$ $a l .^{20}$ This study reviewed 40,000 patients with epilepsy, who were followed for a median of three years. It was determined that the risk of fractures among PWE was two-fold higher compared with the general population. PWE were at increased risk for all types of fractures. PWE were at highest risk for sustaining a hip fracture, with a relative risk of $2.79\left(\mathrm{CI}_{95}: 2.41-3.24\right)$.

These results conflict with some populationbased studies, such as the studies of Beghi and Cornaggia ${ }^{7}$ and Tellez-Zenteno et al. ${ }^{3}$ who found no significant difference in the risk of fracture among PWE and the general population.

Risk factors for fractures among PWE include recent diagnosis of epilepsy, age 45 years or older, male sex, occurrence of generalized seizures, AED polypharmacy, and institutionalization status. ${ }^{18-21}$ The risk of fractures is high in the first two years after diagnosis. ${ }^{18,22,23}$ This may be due to the fact that risk of seizures in epilepsy declines over time,$^{24}$ and patients over the years learn to take precautions to avoid injuries.

Anti-epileptic drugs increase fracture risk as they reduce bone mineral density by increasing vitamin D catabolism and decreasing calcium absorption through induction of liver enzymes. ${ }^{19}$ AEDs that induce the cytochrome p450 system include phenobarbital, phenytoin, primidone, and carbamazepine. The evidence available for the use of noninducing AEDs (i.e. lamotrigine, valproic acid) to reduce AED-related risk is conflicting. ${ }^{25,26}$

\section{Dislocations}

Posterior shoulder dislocations are frequently described in textbooks as being associated with seizures. During a seizure, the shoulder is in a position of adduction, internal rotation, and flexion. In this position, the humeral head is drawn cranially and posteriorly against the glenoid fossa by contraction of the shoulder muscles. The infraspinatus, teres minor, deltoid, latissimus dorsi, and teres major provide the force necessary to dislocate the humerus posteriorly. In the post-ictal period, the humerus is located behind the glenoid fossa, often with a large impression fracture of the head medial to the minor tubercle near the anatomical neck of the humerus (reversed Hill-Sachs lesion). If the seizure continues, the anatomical neck of the humerus is pulled towards the rim of the glenoid fossa, becomes impacted, and can eventually be fractured. ${ }^{27,28}$

Posterior shoulder dislocations are a rare occurrence, comprising $1.5-4.3 \%$ of all shoulder dislocations. ${ }^{28}$ Bilateral posterior shoulder dislocations are even rarer, and some authors have even suggested that such a presentation 
Table 1. Reported injury rates in studies of patients with epilepsy.

\begin{tabular}{|c|c|c|c|c|}
\hline Author & $\begin{array}{l}\text { Country/ } \\
\text { population }\end{array}$ & $\begin{array}{l}\text { Study } \\
\text { type }\end{array}$ & $\begin{array}{l}\text { Number } \\
\text { of patients }\end{array}$ & $\begin{array}{l}\text { Injury } \\
\text { rate }\end{array}$ \\
\hline Nakken and Lossius ${ }^{9}$ & $\begin{array}{l}\text { Norway. Multihandicapped } \\
\text { patients with intractable epilepsy }\end{array}$ & Prospective & 62 cases & $\begin{array}{l}32.3 \% \text { of patients had seizure-related injuries in a } \\
13 \text {-month period }\end{array}$ \\
\hline Ziegler et al. ${ }^{10}$ & $\begin{array}{l}\text { Switzerland. Children with } \\
\text { epilepsy without motor or } \\
\text { mental handicap }\end{array}$ & Retrospective & 198 cases & 6 injuries during 1,056 person-years \\
\hline Kirby and Sadler ${ }^{11}$ & $\begin{array}{l}\text { Canada. Adults with seizures } \\
\text { presenting to the emergency room }\end{array}$ & Prospective & 560 cases & $\begin{array}{l}\text { Incidence of seizures resulting in injury was } 29.5 \text { in } \\
100,000 \text { population } \\
\text { Incidence of seizures causing injury or death in the } \\
\text { general population was } 32.2 \text { in } 100,000 \text { population } \\
15 \% \text { of seizures brought to medical attention resulted } \\
\text { in injury or death }\end{array}$ \\
\hline
\end{tabular}

\begin{tabular}{|c|c|c|c|c|}
\hline Wirrell et al. ${ }^{12}$ & $\begin{array}{l}\text { Canada. Young adults with a history } \\
\text { of typical absence epilepsy. Controls } \\
\text { were young adults with juvenile } \\
\text { rheumatoid arthritis (JRA) }\end{array}$ & $\begin{array}{l}\text { Retrospective } \\
\text { chart review }\end{array}$ & $\begin{array}{l}59 \text { patients/ } \\
61 \text { controls }\end{array}$ & $\begin{array}{l}\text { 24.6/100 person-years injury rate for children with AE, } \\
\text { compared to } 18.7 \text { for children with JRA }(\mathrm{P}<0.04)\end{array}$ \\
\hline Buck et al. ${ }^{4}$ & $\begin{array}{l}\text { UK. Adults with active epilepsy } \\
\text { without severe physical or } \\
\text { learning disabilities }\end{array}$ & $\begin{array}{l}\text { Retrospective } \\
\text { population-based } \\
\text { survey }\end{array}$ & 696 & $35 \%$ sustained a seizure-related injury in the past year \\
\hline Neufeld et $a l^{13}$ & Israel. Adults with epilepsy & $\begin{array}{l}\text { Retrospective } \\
\text { survey }\end{array}$ & 298 & $\begin{array}{l}30 \% \text { of patients reported seizure-related injury. } \\
\text { This translates to one seizure-related injury every } 21 \\
\text { patient-years, and a serious injury once every } 64 \text { patient-years }\end{array}$ \\
\hline Kirsch and Wirrell ${ }^{14}$ & $\begin{array}{l}\text { Canada. Cases were cognitively } \\
\text { normal children aged } 5 \text {-16 with } \\
\text { epilepsy attending a pediatric } \\
\text { neurology clinic. Controls were } \\
\text { the children's 'best friends' }\end{array}$ & $\begin{array}{l}\text { Retrospective } \\
\text { case-control } \\
\text { study }\end{array}$ & $\begin{array}{l}25 \text { cases/ } \\
25 \text { controls }\end{array}$ & $\begin{array}{l}\text { Injuries in the past year not requiring medical treatment } \\
\text { occurred at a median of } 1 \text { ( } 25 \text { th- } 75 \text { th percentile } 0.4) \\
\text { for cases and at a median of } 0(0.5) \text { for controls }(\mathrm{P}=0.81) \\
14 \% \text { of cases had sustained at least } 1 \text { injury as a result of } \\
\text { a seizure in their lifetime }\end{array}$ \\
\hline Beghi and Cornaggia ${ }^{7}$ & $\begin{array}{l}\text { Italy, Germany, Holland, England, } \\
\text { Portugal, Russia, Estonia, Slovenia. } \\
\text { Children } \geq 5 \text { years and adults, study } \\
\text { general hospital and university cente } \\
\text { Healthy controls }\end{array}$ & $\begin{array}{l}\text { Prospective, } \\
\text { case-control }\end{array}$ & $\begin{array}{l}951 \text { cases/ } \\
909 \text { controls }\end{array}$ & $\begin{array}{l}\text { At } 12 \text { months: injury in } 17 \% \text { of cases and } 12 \% \text { of controls } \\
\text { At } 24 \text { months: injury in } 27 \% \text { of cases and } 17 \% \text { of controls } \\
(\mathrm{P}<0.0001)\end{array}$ \\
\hline Appleton $^{15}$ & $\begin{array}{l}\text { UK. Newly diagnosed children } \\
\text { 1-16 years attending one of seven } \\
\text { UK hospitals }\end{array}$ & Prospective & 198 children & $\begin{array}{l}12.6 \% \text { of children experienced a seizure-related injury } \\
\text { before the diagnosis of epilepsy was established. }\end{array}$ \\
\hline Lawn et al. ${ }^{8}$ & $\begin{array}{l}\text { USA. Patients diagnosed with } \\
\text { epilepsy between } 1975 \text { and } 1984\end{array}$ & $\begin{array}{l}\text { Retrospective } \\
\text { chart review }\end{array}$ & 247 adults & $\begin{array}{l}62 \text { seizure-related injuries identified in } 39 \text { patients } \\
\text { over } 2,714 \text { patient-years of follow-up (16\%, one injury in } \\
\text { every } 44 \text { person-years) }\end{array}$ \\
\hline Tellez-Zenteno et $a l^{3}{ }^{3}$ & $\begin{array}{l}\text { Canada. Unselected patients } \\
\text { with epilepsy in general population. } \\
\text { Control was the general population }\end{array}$ & $\begin{array}{l}\text { Retrospective } \\
\text { survey }\end{array}$ & $\begin{array}{l}835 \text { cases, } \\
130,882 \\
\text { controls }\end{array}$ & $\begin{array}{l}14.9 \% \text { of persons with epilepsy had an injury causing } \\
\text { limitation of normal activities in the past } 12 \text { months compared } \\
\text { to } 13.34 \% \text { of the general population }(\mathrm{P}<0.05) \text {. } \\
\text { This yields an RR of } 1.1 \text { (CI95: } 0.8-1.4)\end{array}$ \\
\hline
\end{tabular}

could be pathognomonic of a convulsive disorder. $^{27,29,30}$ Although seizure disorders are commonly linked with posterior shoulder dislocations, anterior dislocations have also been reported. In one study of 26 patients with shoulder dislocations caused by an epileptic seizure, the frequency of anterior and posterior shoulder dislocations was equal..$^{30}$ The same study also found that the dislocations in this group of patients were associated with a high number of Hill-Sachs lesions.

The suspicion of posterior shoulder dislocation should arise in the PWE who present with pain or stiffness of the shoulder after a seizure. The arm will be in a position of adduction and internal rotation, and the patient will not be able to abduct and externally rotate the arm. The diagnosis of posterior shoulder dislocation is often missed, but axillary X-ray or CT scan should help diagnosis. Surgical treatment is required for shoulder dislocations to obtain clinical stability, and anterior shoulder dislocations are noted to be more difficult to treat. ${ }^{30}$ Medical stabilization of epilepsy and compliance with medications will reduce the frequency of seizures and therefore help prevent shoulder dislocations in PWE.

Thus, posterior shoulder dislocations are a rare event; however, one should be aware of their association with seizure disorders. Other dislocations that can occur in PWE include dislocations of the hip and dislocations of the temporomandibular joint. ${ }^{28}$

\section{Motor vehicle accidents}

Driving is an issue of concern among PWE and their physicians, as unprovoked seizures while driving undoubtedly puts the patient and the public at risk for accidents and injuries. Legislation regarding licensing PWE varies from country to country and state to state. In the United States and Canada, patients are required to be seizure-free for 3-12 months before driving, ${ }^{31,32}$ whereas the United Kingdom requires a one-year seizure-free interval before granting or renewing a driving license, although most require a two year period ${ }^{33}$ In six American states, five Canadian provinces and several other countries, manda- 
Table 2. Traffic accidents and seizures.

\begin{tabular}{|c|c|c|c|c|c|}
\hline Author & Country & $\begin{array}{l}\text { Study } \\
\text { description }\end{array}$ & $\mathbf{N}$ & Risk of accident & Conclusion of study \\
\hline Sheth et $a l^{32}$ & $\begin{array}{l}\text { United } \\
\text { States }\end{array}$ & $\begin{array}{l}\text { Analysis of multiple- } \\
\text { cause of mortality } \\
\text { data files from } \\
\text { 1995-1997 }\end{array}$ & $\begin{array}{l}44.027 \text { fatal } \\
\text { crashes/annum } \\
(43,884-44,186)\end{array}$ & $\begin{array}{l}\text { Relative risk for fatal } \\
\text { crashes in seizure patients } \\
=8.6 / 100,000\end{array}$ & $\begin{array}{l}0.2 \% \text { of fatal crashes in the US } \\
\text { related to seizures (1995-1997) } \\
\text { Although seizure-related driver fatalities are rare, } \\
\text { there is an increased risk of fatal crash for drivers } \\
\text { with epilepsy compared to patients with other } \\
\text { medical conditions } \\
\text { Majority of fatal crashes are associated with alcohol } \\
\text { abuse and other crash risk factors, such as driver } \\
\text { error and driving conditions }\end{array}$ \\
\hline van der Lugt ${ }^{38}$ & Netherlands & $\begin{array}{l}\text { Analysis of Netherlands } \\
\text { police records from } \\
\text { January } 1,1959- \\
\text { December } 31,1968\end{array}$ & $\begin{array}{l}203 \text { traffic } \\
\text { accidents } \\
\text { suspected to be } \\
\text { seizure-related }\end{array}$ & $\begin{array}{l}\text { Rate of } \\
\text { seizure-related } \\
\text { traffic accidents } \\
\text { is } 1 / 10,000\end{array}$ & $\begin{array}{l}155 / 203 \text { traffic accidents were attributable } \\
\text { to seizures } \\
\text { Accidents due to epilepsy differed from } \\
\text { the "average traffic accident" in that many } \\
\text { more involved slight injury and } 80 \% \text { involved } \\
\text { only the driver's car (vs. } 75 \% \text { of "average accidents" } \\
\text { involving collision of two or more vehicles) }\end{array}$ \\
\hline $\begin{array}{l}\text { Hansotia } \\
\text { and Broste }\end{array}$ & $\begin{array}{l}\text { United } \\
\text { States }\end{array}$ & $\begin{array}{l}\text { Population-based } \\
\text { retrospective } \\
\text { cohort study }\end{array}$ & $\begin{array}{l}30,420 \text { subjects } \\
\text { with and without } \\
\text { epilepsy or } \\
\text { diabetes } \\
\text { mellitus }\end{array}$ & $\begin{array}{l}\text { Standardized mishap ratios } \\
\text { was } 1.13 \text { for moving } \\
\text { violations }(\mathrm{P}=0.26) \text { and } 1.33 \\
\text { for accidents }(\mathrm{P}=0.04) \text {. }\end{array}$ & $\begin{array}{l}\text { Drivers with epilepsy have slightly increased } \\
\text { risks of traffic accidents as compared } \\
\text { with unaffected persons. }\end{array}$ \\
\hline Taylor et al. ${ }^{37}$ & UK & $\begin{array}{l}\text { Retrospective survey } \\
\text { of driving and accident } \\
\text { experience by self- } \\
\text { completion questionnaire } \\
\text { by drivers with a history } \\
\text { of epilepsy and non- } \\
\text { epileptic drivers } \\
\text { as a control. }\end{array}$ & $\begin{array}{l}16,958 \text { drivers with a } \\
\text { previous history } \\
\text { of epilepsy } \\
8,888 \text { non-epileptic } \\
\text { drivers }\end{array}$ & $\begin{array}{l}\text { Odds ratio for risk of } \\
\text { accident involvement } \\
=0.95\left(\mathrm{CI}_{95} \% 0.88-1.02\right) \\
\text { Adjusted relative risk for } \\
\text { being involved n an accident } \\
\text { resulting in injury is } 1.1 \\
\left(\mathrm{CI}_{95} \% 0.91-1.3\right) \text {. } \\
\text { Adjust odds ratio } \\
\text { for risk of serious injuries } \\
=1.37 \text { ( } \mathrm{CI}_{95} \% \text { 1.02-1.84) }\end{array}$ & $\begin{array}{l}\text { The acceptability of driving for people with a history } \\
\text { of epilepsy should be determined by an } \\
\text { acceptable risk of accidents resulting in injury } \\
\text { or serious injury rather than overall accident rates. }\end{array}$ \\
\hline $\operatorname{Lings}^{39}$ & Denmark & $\begin{array}{l}\text { Analysis of a } 10 \text {-year } \\
\text { historical cohort register } \\
\text { study }\end{array}$ & $\begin{array}{l}159 \text { patients } \\
\text { with epilepsy } \\
\text { and } 559 \text { matched } \\
\text { controls }\end{array}$ & $\begin{array}{l}\text { Relative accident risk } \\
=7.01\left(\mathrm{Cl}_{95} \% 2.18-26.13\right. \\
\mathrm{P}=0.0003)\end{array}$ & $\begin{array}{l}\text { Drivers with epilepsy are more likely than healthy } \\
\text { controls to be treated at a casualty department } \\
\text { after having a motor vehicle accident. }\end{array}$ \\
\hline
\end{tabular}

tory reporting is also required of physicians. ${ }^{34,35}$

In a retrospective analysis over two years of death certificates from the National Center for Health Statistics, Sheth et al. . $^{32}$ compared annual totals and disease-specific risk for fatal crashes associated with seizures and other medical conditions: $0.2 \%$ of motor vehicle accidents in the United States between 1995-1997 were related to seizures. The rate for fatal seizure-related crashes among PWE was $8.6 / 100,000$. The rate for fatal crashes in the general population was 2.6 times greater than for those with epilepsy. People with associated alcohol abuse had a fatal crash rate 8 times greater than patients with epilepsy. However, the relative risk for fatal crashes for patients with seizures is 2.3 times higher than for those with cardiovascular or hypertensive disease, and 4.6 higher than for patients with diabetes. Thus, although the rate of fatal motor vehicle accidents in PWE is low, having a seizure disorder increases the likelihood that a person will have an accident while driving. This agrees with other reports in the litera- ture, which have found that road accidents due to epilepsy are few in number and there is only a moderate risk of driving accidents in PWE. . $^{1,6-38}$ In a 10-year historical cohort study of 159 subjects with epilepsy and 559 individually matched controls, it was found that there was a seven-fold increased risk of emergency department visits after a car accident in epileptic patients. ${ }^{30}$ This data should be taken cautiously as the sample size in the study was small (Table 2).

Identified factors that reduce the risk of having a seizure-related driving accident include long seizure-free intervals, reliable auras, few prior non-seizure related accidents, and good compliance with AEDs. ${ }^{40}$ In patients who had a 12-month or longer seizure-free interval, the risk of having a road accident was reduced by $93 \%$. Having reliable auras reduces the risk of a driving accident as it allows the the patient to remove himself from the road before experiencing a seizure. Twenty-six percent of patients will still have a motor vehicle accident despite having an aura, and this may be due to a short aura, traffic conditions that make it difficult for the driver to pull aside, and the belief that one can make it home before the seizure occurs. On a point of interest, female drivers with epilepsy have fewer accidents than male drivers with epilepsy. ${ }^{35,41,42}$

\section{Burns}

The population-based epidemiological study of Tellez-Zenteno et al. ${ }^{3}$ indicated that persons with epilepsy had a higher frequency of burns than the general population $(6.9 \%$ vs. $3.9 \%$ ). Unfortunately, the small sample size did not allow for an accurate analysis of the increase in relative risk for burns in patients with epilepsy. Burns as a consequence of an epileptic seizure account for 1.6$10 \%$ of admissions to burns units. ${ }^{43-47}$ The majority of burns in epileptic patients occur while carrying out daily routine activities, such as cooking, ironing, blow-drying hair, or 
Table 3. Characteristics of common injuries associated with epilepsy.

\begin{tabular}{lll}
\hline Type of injury & Characteristics & Risk factors \\
Head injury/concussion & Most common type of injury among epileptics & Generalized seizures \\
Burns & Majority of burns in epileptic patients occur while carrying & Number of seizures \\
& Cut daily routine activities, such as cooking, ironing, blow- \\
drying hair, or bathing & & Complex-partial seizures \\
& Female gender & Lack of neurological deficits \\
\hline Fractures & Commonly in the forearm, humerus, or crush injuries in the & Recent diagnosis of epilepsy \\
& spine due to violent muscle contractions & Age $\geq 45$ years \\
& Risk highest in the first 1-2 years after diagnosis & Male sex \\
& Anti-epileptic drugs increase fracture risk by reducing bone & Generalized seizures \\
& mineral density by increasing vitamin D catabolism and & AED polypharmacy \\
decreasing calcium absorption through induction of liver enzymes & Institutionalization \\
Dislocations & Bilateral posterior shoulder dislocations pathognomonic for epilepsy & Generalized seizures \\
& Actual incidence of posterior shoulder dislocations is extremely low & Prolonged generalized seizures \\
& Dislocations commonly associated with Hill-Sachs lesions & Short seizure-free intervals \\
Dislocations of hip and TMJ also described & Unreliable auras \\
\hline Motor vehicle accidents & Despite driving restrictions being placed on PWE, the rate of & Prior non-seizure related accidents \\
& fatal motor vehicle accidents in PWE is low; however, having & Non-compliance with AEDs \\
\hline
\end{tabular}

TMJ: temporomandibular joint. PWE: patient with epilepsy.

bathing. Domestic scalds have become the most common cause of admission in burned patients with epilepsy. ${ }^{43}$

In a retrospective review of a burn center registry, it was found that $72 \%$ of burns in epileptic patients were full-thickness burns, compared to $68 \%$ in the general burn population. ${ }^{48}$ These full-thickness burns require hospital admission and surgery to promote healing, retain function, and reduce scarring. In contrast to the findings of Josty et al., ${ }^{43}$ this particular study found that the majority of burns in epileptic patients were due to fire/flame while cooking.

Identified risk factors for PWE sustaining a burn injury include number and type of seizure, female gender, and presence of neurological deficit. The more seizures individuals have, the more likely they are to suffer from a burn injury. ${ }^{49}$ Occurrence of a complex partial seizure also correlated with the likelihood of a burn during seizure. ${ }^{50}$ Women are twice as likely to sustain a burn injury due to epilepsy, and this is likely due to the fact that women more often carry out cooking duties and hair-styling tasks associated with epileptic burns. Spitz et al. ${ }^{49}$ also found that having a neurological deficit was protective against burns, possibly because patients with a neurological deficit are less likely to perform dangerous tasks for themselves, or will do these tasks under supervision.

Several guidelines and prevention strategies have been developed in order to protect those with epilepsy from sustaining a burn injury. These strategies include use of the microwave over the stove, having the bath water temperature at $48.9^{\circ} \mathrm{C}$, and having a shower rather than a bath. ${ }^{48}$

\section{Activity and location in which injuries occur}

The majority of injuries in PWE occur at home. ${ }^{1,3}$ In a European cohort study, van den Broek and Beghi ${ }^{1}$ found that PWE had a significantly higher risk of sustaining injury in the home environment compared to non-epileptic controls. For PWE, the cumulative time-dependent chance of an accident at home was 7\% by 12 months and $11 \%$ by 24 months, compared with $3 \%$ and $5 \%$ for controls $(\mathrm{P}<0.0001)$. PWE continue to have a higher risk for domestic accidents even when seizure-related accidents were excluded ( $5 \%$ and $8 \%$; $\mathrm{P}<0.01$ ). TellezZenteno et al. also obtained a similar observation with $41.4 \%$ of PWE having injuries at home compared to $33.1 \%$ of the general population (RR: 1.3, $\mathrm{CI}_{95}$ : 0.8-1.7). ${ }^{4}$ Van den Broek and Beghi also found that PWE have a significantly higher number of injuries on the street and in the workplace compared to the general population. The study of Tellez- Zenteno et al. obtained similar results, however it was not possible to analyze the data of these results for because the small sample size.

It is interesting to note that van den Broek and Beghi did not find a significant difference between injuries occurring during sports in PWE and the general population, and TellezZenteno et al. actually found that significantly fewer PWE experienced sports-related injuries when compared to the general population (32.1\% vs. 43.8, RR: 0.7, $\mathrm{CI}_{95}$ : 0.4-0.9). This finding can be attributed to the fact that PWE may be more cautious during sporting activities and participate in fewer group sporting

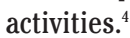

\section{Hospitalizations}

It is a well-established fact that PWE have more hospital admissions than the general population. The CDC estimated that approximately 93,000 hospitalizations each year are attributed to epilepsy, ${ }^{51}$ and in their populationbased epidemiological study, Tellez-Zenteno et $a l^{3}$ determined that among individuals who received care within 48 hours, hospital admissions following injuries were three times more frequent in persons with epilepsy as compared to the general population $(24.2 \%$ vs. $8.1 \%$, RR: 3.0, $\mathrm{CI}_{95}$ : 1.3-4.7). The injuries in PWE were no more severe than those sustained in the general population. Other studies have also noted the same trend in increased hospitalizations among persons with epilepsy (3\% of patients vs. $1 \%$ of controls). ${ }^{1}$ In the study by van de Broek and Beghi, ${ }^{1}$ fractures were the most common reason for hospital admission. Apart from hospitalizations due to injuries, it has also been found that PWE are more often hospitalized for general illnesses than controls (24\% vs. $6 \% ; \mathrm{P}<0.0001$ )

In a study of hospital records from the health district of South Glamorgan from 19911995 by Currie et al. ${ }^{52}$ it was determined that epileptic patients were responsible for $2.8 \%$ of hospital admissions. The rate of admissions with epilepsy as the primary diagnosis was $94 / 100,000$ population per year, and the largest proportions of admissions was to pediatric neurology (53.4\%), those due to mental handicap (25.1\%) and to neurosurgery (9.1\%). It was also found that the average length of stay was longer for those with epilepsy than for the general population (24.8 days vs. 9.1 days). It was 
concluded that PWE comprise a significant portion of hospital admissions and occupy patient beds for a longer time than the general population. This overburdens healthcare resources. The authors suggested that there may be evidence for cost-containment by reducing multiple admissions.

Possible explanations for the higher incidence of hospital admissions in PWE include a more cautious attitude of clinicians toward injuries occurring in the setting of seizures, hospitalizations required because of seizures and not because of the injuries themselves, hospitalization driven by other issues, such as comorbidities, which are highly prevalent in patients with epilepsy, and possibly more severe injuries in PWE than in the general population $^{3}$ (Table 3 ).

Factors that contribute to a higher likelihood of hospital admission among epileptic patients include higher seizure frequency and lower quality of life. Age, marital status, race/ethnicity, educational level, and annual household income are not associated with higher rates of hospital admission..$^{33}$

\section{Risk factors}

There are several risk factors that lead to increased risk of injury in general. Seizure type has the highest correlation with increased injury risk. Generalized tonic-clonic seizures, atonic seizures, and complex partial seizures are associated with the highest risk of injury because of the alteration in or loss of consciousness. ${ }^{54}$ Patients having at least one seizure a month, and with more than three adverse effects due to antiepileptic drugs are also more likely to sustain an injury due to seizures. Epilepsy duration, sex, and age are not significant risk factors. ${ }^{5}$

Risk of injury in an epileptic patient affects employability, insurance eligibility, and education and recreational opportunities. ${ }^{8.55-57}$ It is noted that patients with active epilepsy are at increased risk for injury, ${ }^{1}$ and therefore it is important to keep epilepsy under pharmacological remission in order to reduce the risk of injury to the patient, thereby allowing the patient to enjoy normal occupational and social privileges, and an improved quality of life.

\section{Prevention}

There are general guidelines in place to prevent injury in those with epilepsy. For all patients, epilepsy should be treated to reduce seizure frequency, drug-related balance problems should be minimized, swimming should be supervised, and regular exercise should be undertaken to maintain bone mass. Patients at higher risk (those with the risk factors as defined above) should avoid unsupervised bathing, minimize burn risks, and avoid high places. $^{5}$

The International League Against Epilepsy has laid out guidelines for prevention of injury in children. ${ }^{55}$ The guidelines have few restrictions on activity, but there is the stipulation that children should be monitored while bathing, while using the stove or oven, and during sports and recreational activities. These principles are time-limited. For example, restrictions to activity and supervision should be undertaken: (a) for 2-3 months after a first untreated seizure; (b) after treatment is initiated and until it can be determined that further seizures are unlikely; and (c) for a few months after antiepileptic drugs have been discontinued. Restrictions may be required indefinitely in children who have persistent recurrent seizures which are not controlled by treatment.

By and large, the risk of injury to patients with controlled epilepsy is small, and these patients should be encouraged to enjoy as normal a lifestyle as possible.

\section{References}

1. van den Broek M, Beghi E, for the REST-1 group. Accidents in patients with epilepsy: types, circumstances, and complications: a European cohort study. Epilepsia 2004;45: 667-72.

2. Aldenkamp A, Arends J. The relative influence of epileptic EEG discharges, short nonconvulsive seizures, and type of epilepsy on cognitive function. Epilepsia 2004;45:54-63.

3. Tellez-Zenteno JF, Hunter G, Wiebe S. Injuries in people with self-reported epilepsy: a population-based study. Epilepsia 2008;49:954-61.

4. Buck D, Baker GA, Jacoby A, et al. Patients' experiences of injury as a result of epilepsy. Epilepsia 1997;38:439-44.

5. Spitz MC. Injuries and death as a consequence of seizures in people with epilepsy. Epilepsia 1998;39:904-7.

6. Beghi E. Injuries in patients with epilepsy. Lancet neurol 2005;4:71-2.

7. Beghi E, Cornaggia C, RESt-1 G. Morbidity and accidents in patients with epilepsy: results of a European cohort study. Epilepsia 2002;43:1076-83.

8. Lawn ND, Bamlet WR, Radhakrishnan K, et al. Injuries due to seizures in persons with epilepsy: a population-based study. Neurology 2004;63:1565-70.

9. Nakken KO, Lossius R. Seizure-related injuries in multihandicapped patients with therapy-resistant epilepsy. Epilepsia 1993;34:836-40.

10. Ziegler AL, Reinberg 0, Deonna T. Epilepsy and accidents: what is the risk in children? Arch Pediatr 1994;1:801-5.

11. Kirby S, Sadler RM. Injury and death as a result of seizures. Epilepsia 1995;36:25-8.

12. Wirrell EC, Camfield PR, Camfield CS, et al. Accidental injury is a serious risk in children with typical absence epilepsy. Arch Neurol 1996;53:929-32.

13. Neufeld MY, Vishne T, Chistik V, Korczyn AD. Life-long history of injuries related to seizures. Epilepsy Res 1999;34:123-7.

14. Kirsch R, Wirrell E. Do cognitively normal children with epilepsy have a higher rate of injury than their nonepileptic peers? J Child Neurol 2001;16:100-4.

15. Appleton RE, Mersey Region Paediatric Epilepsy Interest Group. Seizure-related injuries in children with newly diagnosed and untreated epilepsy. Epilepsia 2002; 43:764-7.

16. Kristiansen B, Christensen S. Fractures of the proximal end of the humerus caused by convulsive seizures. Injury 1984;16:1089.

17. Aboukasm AG, Smith BJ. Nocturnal vertebral compression fracture. A presenting feature of unrecognized epileptic seizures. Arch Fam Med 1997;6:185-7.

18. Persson HB, Alberts KA, Farahmand BY, Tomson T. Risk of extremity fractures in adult outpatients with epilepsy. Epilepsia 2002;43:768-72.

19. Vestergaard P. Epilepsy, osteoporosis and fracture risk - a meta-analysis. Acta Neurol Scand. 2005;112:277-86.

20. Souverein PC, Webb DJ, Petri H, et al. Incidence of fractures among epilepsy patients: a population-based retrospective cohort study in the General Practice Research Database. Epilepsia 2005;46:30410.

21. Nei M, Bagla R. Seizure-related injury and death. Curr Neurol Neurosci Rep 2007;7: $335-41$.

22. Vestergaard P, Tigaran S, Rejnmark L, Tigaran C, Dam M, Mosekilde L. Fracture risk is increased in epilepsy. Acta Neurol Scand 1999;99:269-75.

23. Annegers JF, Melton LJ,3rd, Sun CA, Hauser WA. Risk of age-related fractures in patients with unprovoked seizures. Epilepsia 1989;30:348-55.

24. Cockerell OC, Sander JW, Shorvon SD. Remission of epilepsy. The NGPS. National General Practice Study of Epilepsy. Lancet 1995;346:1228.

25. Stephen LJ, McLellan AR, Harrison JH, Shapiro D, Dominiczak MH, Sills GJ, et al. Bone density and antiepileptic drugs: a case-controlled study. Seizure 1999;8:33942. 
26. Sheth RD, Wesolowski CA, Jacob JC, et al. Effect of carbamazepine and valproate on bone mineral density. J Pediatr 1995; 127:256-62.

27. Shaw JL. Bilateral posterior fracture-dislocation of the shoulder and other trauma caused by convulsive seizures. J Bone Joint Surg Am 1971;53:1437-40.

28. Gosens T, Poels PJ, Rondhuis JJ. Posterior dislocation fractures of the shoulder in seizure disorders--two case reports and a review of literature. Seizure 2000;9:446-8.

29. Silbergeld DL, Harkness WF, Bell BA, Bircher MD. Posterior fracture dislocation of the shoulder secondary to epileptic seizures. J R Coll Surg Edinb 1991;36:13940.

30. Buhler M, Gerber C. Shoulder instability related to epileptic seizures. J Shoulder Elbow Surg 2002;11:339-44.

31. Krauss GL, Ampaw L, Krumholz A. Individual state driving restrictions for people with epilepsy in the US. Neurology 2001;57:1780-5.

32. Sheth SG, Krauss G, Krumholz A, Li G. Mortality in epilepsy: driving fatalities vs other causes of death in patients with epilepsy. Neurology 2004;63:1002-7.

33. Beghi E, Sander JW. Epilepsy and driving. BMJ 2005;331:60-1.

34. Bird S. Epilepsy, driving and confidentiality. Aust Fam Physician 2005;34:1057-8.

35. McLachlan RS, Starreveld E, Lee MA. Impact of mandatory physician reporting on accident risk in epilepsy. Epilepsia 2007:48:1500-5.

36. Hansotia P, Broste SK. The effect of epilepsy or diabetes mellitus on the risk of automobile accidents. N Engl Med 1991;324:22-

\section{6.}

37. Taylor J, Chadwick D, Johnson T. Risk of accidents in drivers with epilepsy. J Neurol Neurosurg Psychiatry 1996;60:621-7.

38. van der Lugt PJ. Traffic accidents caused by epilepsy. Epilepsia 1975;16:747-51.

39. Lings S. Increased driving accident frequency in Danish patients with epilepsy. Neurology 2001;57:435-9.

40. Krauss GL, Krumholz A, Carter RC, Li G, Kaplan P. Risk factors for seizure-related motor vehicle crashes in patients with epilepsy. Neurology 1999;52:1324-9.

41. Masland RL. The physician's responsibility for epileptic drivers. Ann Neurol 1978;4: 485-6.

42. Waller JA. Chronic medical conditions and traffic safety: review of the California experience. N Engl J Med 1965;273:141320.

43. Josty IC, Narayanan V, Dickson WA. Burns in Patients with Epilepsy: Changes in Epidemiology and Implications for Burn Treatment and Prevention. Epilepsia 2000;41:453-6.

44. Tempest M. A survey of domestic burns and scalds in Wales during 1955; some observations on their prevention and the social responsibility of the medical profession. Br Med J 1956;1:1387-92.

45. Maisels D0, Corps BVM. Burned epileptics. Lancet 1964;1:1298-301.

46. Bull J, Jackson DM, Walton C. Causes and prevention of domestic burning accidents. Br Med J 1964;2:1421-7.

47. Richards EH. Aspects of epilepsy and burns. Epilepsia 1968;9:127-35.

48. Rimmer RB, Bay RCR, Foster KN, et al. Thermal Injury in Patients With Seizure
Disorders: An Opportunity for Prevention. Journal of Burn Care Res 2007;28: 318-23.

49. Spitz MC, Towbin JA, Shantz D, Adler LE. Risk factors for burns as a consequence of seizures in persons with epilepsy. Epilepsia 1994;35:764-7.

50. Hampton KK, Peatfield RC, Pullar T, et al. Burns because of epilepsy. Br Med J 1988; 296:1659-60.

51. Centers for Disease Control and Prevention (CDC). Hospitalization for epilepsy - United States, 1988-1992. MMWR Morb Mortal Wkly Rep 1995;44:818-21.

52. Currie CJ, Morgan CL, Peters JR, Kerr M. The demand for hospital services for patients with epilepsy. Epilepsia 1998;39: 537-44.

53. Bautista RE, Glen ET, Wludyka PS, Shetty NK. Factors associated with utilization of healthcare resources among epilepsy patients. Epilepsy Res 2008;79:120-9.

54. Zwimpfer TJ, Brown J, Sullivan I, Moulton RJ. Head injuries due to falls caused by seizures: a group at high risk for traumatic intracranial hematomas. J Neurosurg 1997;86:433-7.

55. ILAE Commission report. Restrictions for children with epilepsy. Commission of Pediatrics of the ILAE. International League Against Epilepsy. Epilepsia 1997; 38:1054-6.

56. Davidson DL, Macdonald S. The costs of trauma caused by seizures: can they be reduced? Seizure 2002;11:344-7.

57. Jones MW. Consequences of epilepsy: why do we treat seizures? Can J Neurol Sci 1998;25:S24-6. 